Bulgarian Academy of Sciences. Space Research and Technology Institute. Aerospace Research in Bulgaria. 31, 2019, Sofia

DOI: https://doi.org/10.3897/arb.v31.e09

\title{
SECONDARY POWER SUPPLY SYSTEM FOR SPACECRAFT POTENTIAL MONITOR DP-1 AND DP-2, "OBSTANOVKA" PROJECT, INTERNATIONAL SPACE STATION
}

\author{
Pavlin Gramatikov, Roumen Nedkov, Georgi Stanev \\ Space Research and Technology Institute - Bulgarian Academy of Sciences \\ e-mail:pgramatikov@space.bas.bg,rnedkov@space.bas.bg
}

Keywords: Spacecraft, International Space Station, Secondary power supply system.

\begin{abstract}
Plasma Wave Complex is a scientific instrumentation for wave parameters measurements in the ISS environment, and is implemented in the OBSTANOVKA experiment on board of Russian segment of ISS. The device Spacecraft Potential monitor "DP-1"and "DP-2" (one part of PlasmaWave Complex) was developed in IKI BAS and measured the potential of the hull no more than $3 \mathrm{~m}$ from the surface of the ISS at range $\pm 200 \mathrm{~V} ; 0 \div 500 \mathrm{~Hz}$. There are block and functional diagrams of the "DP" and the secondary power supply system, designed to supply the measuring probe, analogue and digital circuit boards. The secondary power supply system for the device "DP-1" and "DP-2" is discussed here in detail.
\end{abstract}

\section{Introduction}

The "Charge-ISS" Project from the experiment "Obstanovka" is designed to study the charging of large-scale spacecraft of the International Station (ISS) in interaction with the Earth's Ionosphere plasma. Devices "DP-1" and "DP-2" (Fig. 2) are designed for measurements the electric potential of the ISS with the help of spherical sensors based on carbon fiber. Plasma-wave processes are components part of the Space Weather. This approach is based on one of the contemporary ideas in physics - view on the plasma, including plasma in the outer space as to the dynamic medium with the charged particles and the wide spectrum of plasma wave motions and heterogeneities [1]. The "Obstanovka-1" stage will be carried out to provide a data of electromagnetic fields and of plasma-wave processes occurring in the ISS near surface zone (NSC) to study the plasma component factors of near-Earth space (NES) [3]. On the Fig. 1 [2], is given block-diagram of Plasma-Wave Complex (PWC): Combined wave sensor (CWS); Flux gate magnetometer (DFM); Langmuir probe (LP); Plasma discharge stimulator (SPP); Correlating Electron Spectrograph (CORES); Radio Frequency Analyzer (Scorpion); Signal Analyzer and Sampler (SAS3); Data Acquisition and Control Unit (DACU); Block of Storage of Telemetry 
Information (BSTM), inside ISS. To study the plasma environment parameters, including electromagnetic conditions (EMC) in the vicinity of ISS, PWC will measure fluctuation and gradients of magnetic field, parameters of electrostatic and electromagnetic fields, density and temperature of thermal plasma, thermal electron flows in the ISS near zone and also electric potential of the ISS itself [2]. The PWC is implemented as two measuring blocks with nearly identical sensors. The distance between them $(3-15 \mathrm{~m})$ will enable us to carry out simultaneous point-to point measurements necessary for the measurements of DC electrical fields and small-scale gradients in magnetic field.

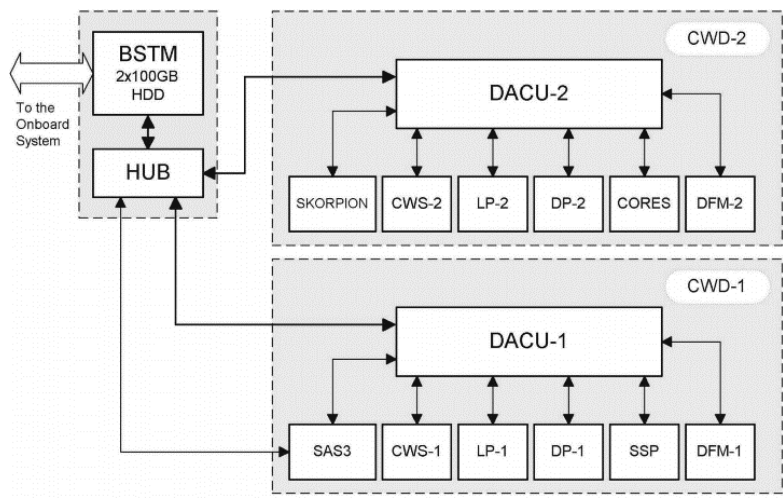

Fig. 1. Plasma-Wave Complex Block diagram [2]

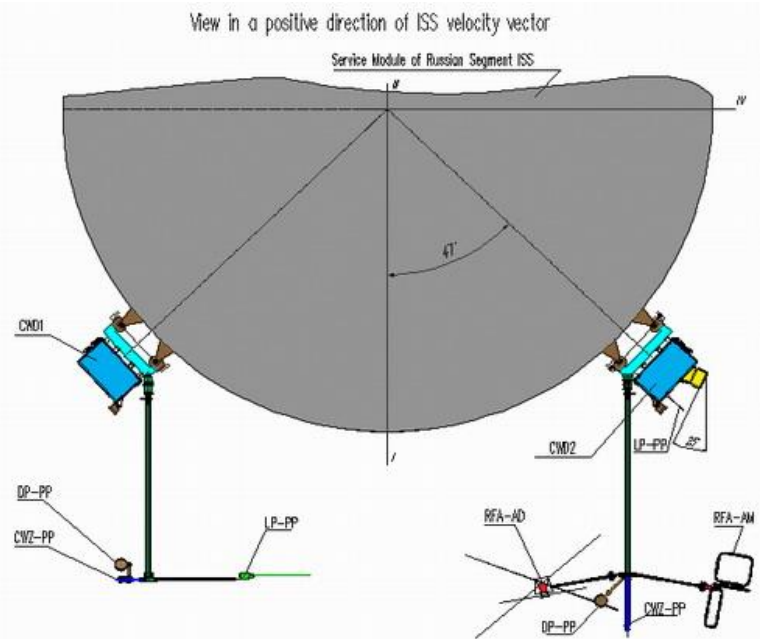

Fig. 3. Plasma-Wave Complex on the ISS board [6]

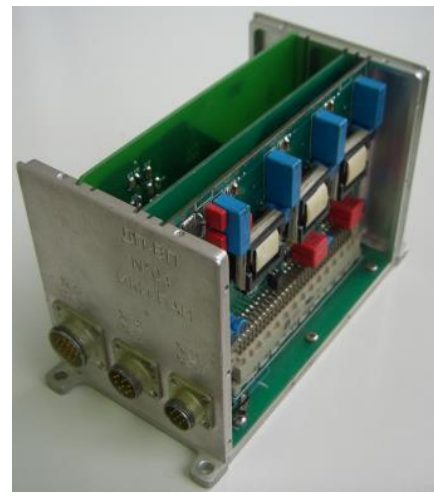

Fig. 2. Spacecraft potential monitor "DP-1" and "DP-2"
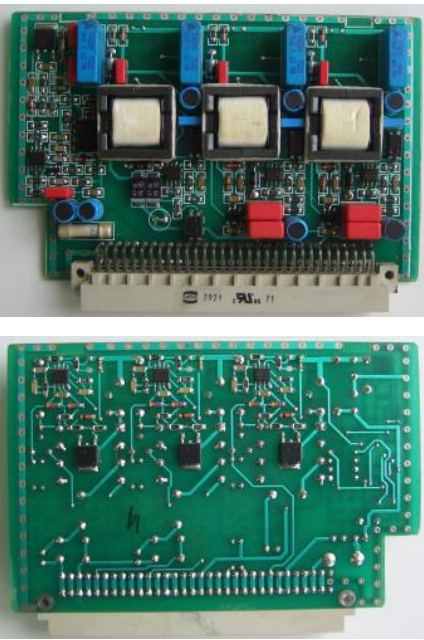

Fig. 4, 5. Secondary power supply system for "DP-1" and

"DP-2" 
The developed PWC scientific equipment is designed to measure in NES the following physical parameters: current parameters of thermal plasma (in two points); electrons and ions temperature, $\mathrm{T}_{\mathrm{e}}, \mathrm{T}_{\mathrm{i}}$; electrons and ions density, $\mathrm{N}_{\mathrm{e}}, \mathrm{N}_{\mathrm{i}}$; current electromagnetic parameters (in two points); DC electric and magnetic fields and currents; AC electric and magnetic fields and currents; current plasma potential and ISS potential; electrons spectra with energy range $0.01-10 \mathrm{keV}$; spectra of VLF electromagnetic fluctuations. For the study of discharge effects in NES plasma the PWC structure includes also the device for discharge stimulation [3].

\section{Materials and methods}

\subsection{Device DP}

The potential difference measurement between a probe and ISS body is the main scientific aim of the device DP. This allows us to study of the ISS electric charging processes and the time variation of the electric potential. The existence of two identical devices DP-1 and DP-2, which are mounted on every block CWD, allows us also to measure the spatial electric field in NSZ [3]. Each of them contains sensor - electronic Converter unit DP-PP (Primary Converter) and the electronic unit DP-SP (Secondary Converter). The device DP also provides an estimation of the contact layer resistance of the system plasma-probe. For Fig. 3 the designation DPPP for the sensors of the device "DP" is accepted. Two devices "DP-1" and "DP-2" are mounted inside CWD1 and CWD2 respectively. The device DP is an electronic module which measures the potential difference in range $\pm 200 \mathrm{~V}$, which is divided in two sub-ranges: $\pm 20 \mathrm{~V}$ and $\pm 200 \mathrm{~V}$. The subranges are switched automatically. Device DP-SP (Fig. 2) consist from three boards: SPS-DP; analog processing and quantization board of input signals and microcomputer board. A 12-bit ADC (Fig. $3)$ provides potential difference measurements with resolution $10 \mathrm{mV}( \pm 20 \mathrm{~V})$ and $100 \mathrm{mV}( \pm 200 \mathrm{~V})$. The DP device measures and transmits information about the potential of the ISS body to the following information modes (measurements per second) [7]: fast 200; working: 100, 50, 20, and 12.5; base: 10, 8, 4, 2, and 1.25; slow: $1,0.8$, and 0.5 ; duty 0.33 .

The probes of the device DP is the spherical collapsible structures with a diameter of $80 \mathrm{~mm}$. Hemispheres are made of graphite and coated glass-carbon coating, which provides minimal variations in the value of the work electron output over the entire surface of the probes [7].

The DP instrument has passed functional tests and communication tests in the composition of the whole complex of scientific instruments in Russia and Hungary. The secondary source for powering a DP must meet all the requirements for scientific equipment for work on the outside of the ISS [5]. "DP-1" and "DP-2" instruments must undergo vacuum tests with simulated sun. The specific methodology shall be developed for each of the operating outside the ISS. The cutlery are tested in three modes: 
- Permanent, with the inclusion of "sun" for $4.5 \mathrm{~h}$;

- Periodically, tricikla with an imitation of the entry in the Shadow of the Earth (57 minutes "sun" and 36 minutes - shadow of the Earth);

- In the absence of a solar radiation, with an imitation of the Earth's radiation in the course of $4.5 \mathrm{~h}$.

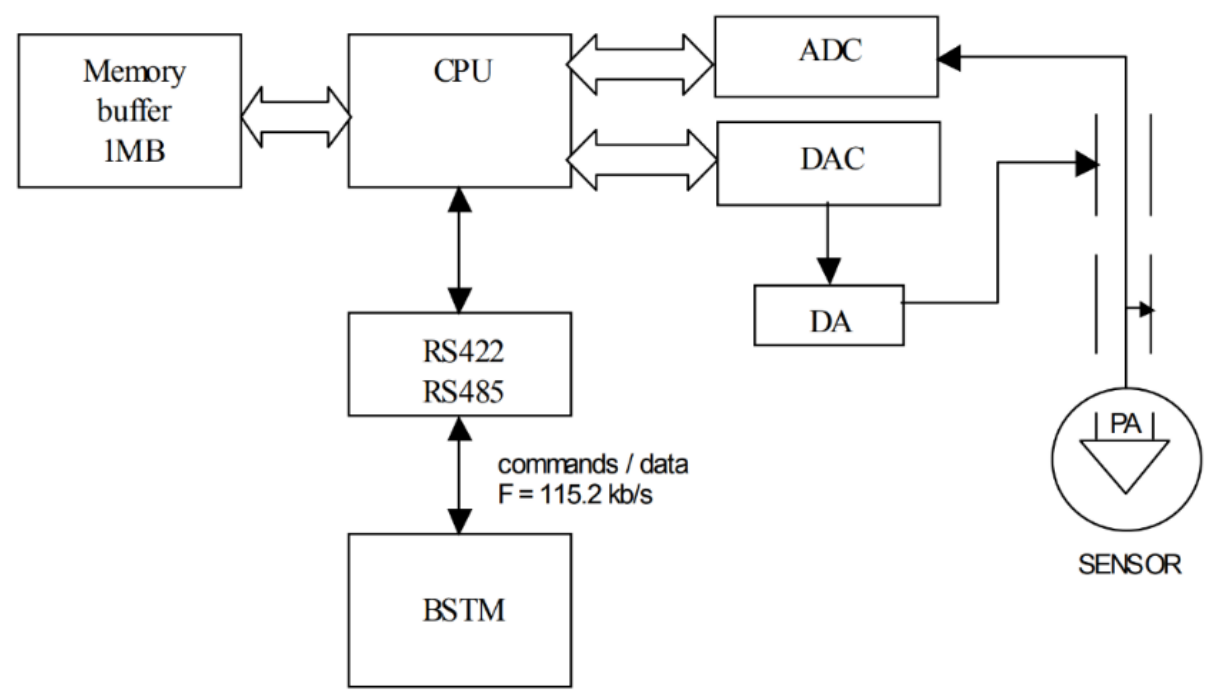

Fig. 6. Block diagram of Spacecraft potential monitor DP [3]

\subsection{Secondary power supply system for device DP}

The secondary power supply system has galvanic insulation between primary power lines and the secondary power lines. The connection with the main power supply is designed so that no instrument failure can influence other units. The instrument total power limit is $\sim 4.7 \mathrm{~W}$. The starting characteristics of the SPS-DP for the "DP" instrument were measured. In a Table 1 are given the electrical parameters of SPS-DP fly set (FS): FS-1, 2, 3, and 4, measured at maximum load (simulated by a resistive load exceeding the real load), idling and no secondary part. It is noticeable that with an increase in $\mathrm{BN}$ from $17 \mathrm{~V}$ to $36 \mathrm{~V}$, the efficiency deteriorates by about $10 \%$. Functional scheme of SPS-DP for devices DP is given on the Fig. 7. The technical documentation for "DP" is compiled. The dimensions of the component of SPS-DP are $122 \times 78 \mathrm{~mm}$ and the overall height of the components of the transformers side is $11 \mathrm{~mm}$, Fig. 5 . 
Table 1. Parameters of SPS-DP, FS-1, 2, 3, and 4 for instrument "DP-1" and "DP-2"

\begin{tabular}{|l|c|c|c|c|c|c|c|}
\hline $\begin{array}{l}\text { SPS Fly Set } \\
1,2,3, \text { and } 4\end{array}$ & U-5M [V] & 17 & 19 & 23 & 29 & 34 & 36 \\
\hline FS-1, Pout $=2,1 \mathrm{~W}$ & efficiency [\%] & 68.13 & 68.24 & 67.56 & 63.21 & 59.05 & 57.28 \\
\hline FS-1, $P_{\text {out }}=2,1 \mathrm{~W}$ & power BN [mW] & 3094 & 3089 & 3120 & 3335 & 3570 & 3680 \\
\hline FS-2, P out $=2,1 \mathrm{~W}$ & efficiency [\%] & 68.13 & 68.49 & 67.89 & 63.76 & 59.05 & 57.44 \\
\hline FS-2, P out $=2,1 \mathrm{~W}$ & power BN [mW] & 3094 & 3078 & 3105 & 3306 & 3570 & 3670 \\
\hline FS-2, P out $=2,1 \mathrm{~W}$ & efficiency [\%] & 67.39 & 67.65 & 67.39 & 63.76 & 59.05 & 57.41 \\
\hline FS-2, Pout $=2,1 \mathrm{~W}$ & power BN [mW] & 3128 & 3116 & 3128 & 3306 & 3570 & 3672 \\
\hline FS-4, Pout $=2,1 \mathrm{~W}$ & efficiency [\%] & 67.83 & 68.49 & 68.40 & 64.33 & 59.62 & 57.98 \\
\hline FS-4, $P_{\text {out }}=2,1 \mathrm{~W}$ & power BN [mW] & 3107.6 & 3078 & 3082 & 3277 & 3536 & 3636 \\
\hline FS-3, Pout $=0 \mathrm{~mW}$ & power BN [mW] & 85 & 100.7 & 184 & 377 & 588.2 & 684 \\
\hline FS-4, Pout $=0 \mathrm{~mW}$ & power BN [mW] & 85 & 100.7 & 184 & 377 & 588.2 & 684 \\
\hline
\end{tabular}

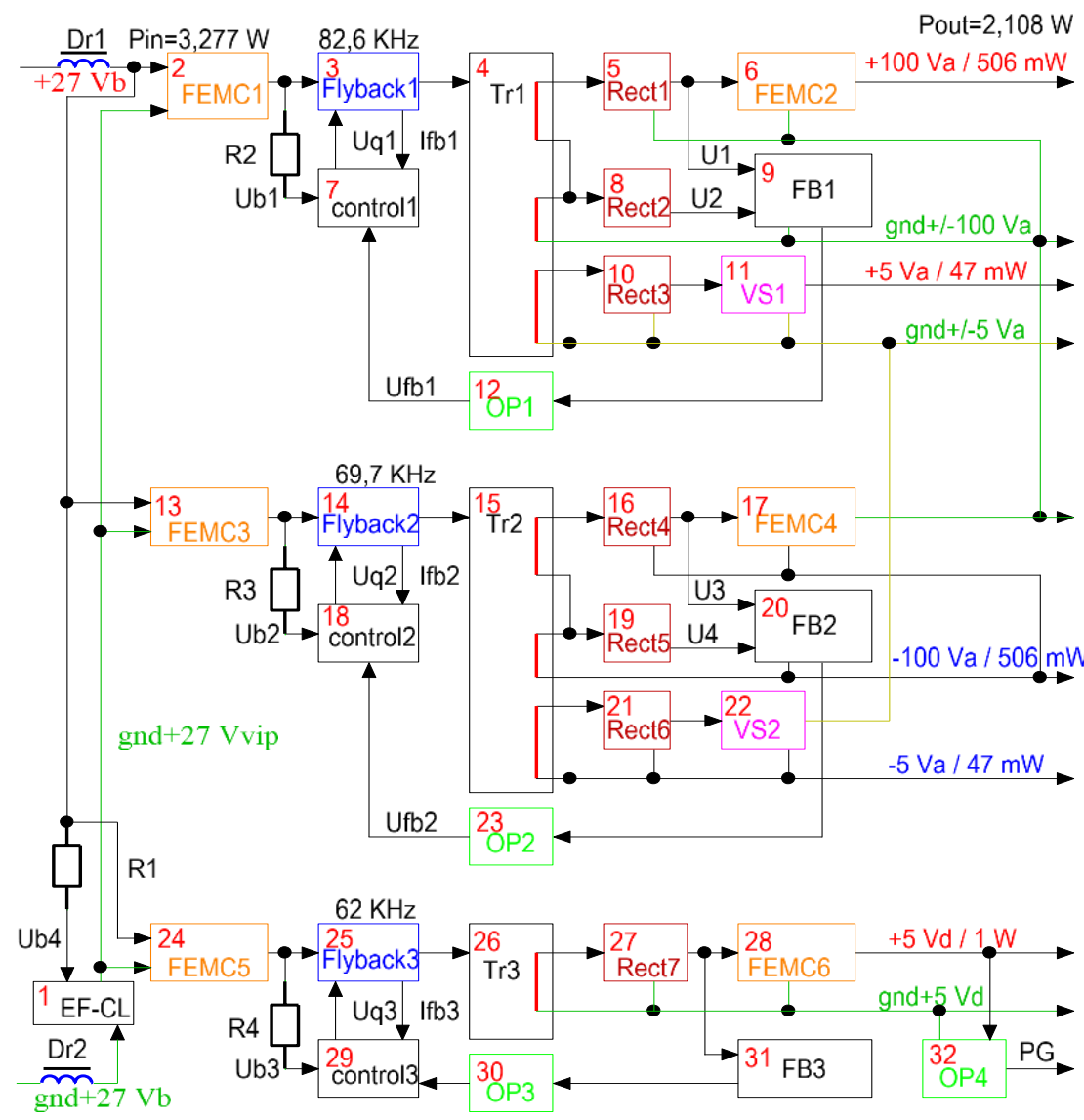

Fig. 7. Functional scheme of SPS-DP for Devices DP 
The voltage of the boarding net $(\mathrm{BN})$ shall be transmitted through chokes (Dr1 and Dr2) according to the technical requirements [5]. The EF-CL (1) unit has functions of electronic fuse (EF) and current limit (CL). The power supply for (1) from $\mathrm{BN}$ is done simply by $\mathrm{R} 1$. When the output current of (1) exceeds a certain limit, it is limited. If the duration of this condition exceeds a specified time (1) excludes the submission of BN to the SPS while retaining this state of ,stand by" while BN does not restart.

The SPS-DP is made up of three reverse convertors. Accordingly, the first A is made up of the elements (2-12), the second B of (13-23) and the third C of (24-32).

Voltages " $\pm 100 \mathrm{Va}$ " with their mass "gnd $\pm 100 \mathrm{Va}$ " serve to supply the Sensor; " $\pm 5 \mathrm{Va}$ " with their mass "gnd $\pm 5 \mathrm{Va}$ " power up he ADC and DA, and the digital blocks (Fig. 6) are powered by " $\pm 5 \mathrm{Vd}$ " with their mass "gnd $\pm 5 \mathrm{Vd}$ ".

Converter A works as follows: 1 powered 2, R2 via Ub1 powered 7. After the start-up process of 7 appears the impulses Uq1 for normal operation of 3 . The current Ifb1 of 3 is monitored dynamically for each period of Uq1. The Tr1 transformer serves as a galvanic insulation and with 5 and 6 generates the main voltage $\mathrm{U} 1$, the auxiliary voltage $\mathrm{U} 2$, and by 10 and 11 -stabilized voltage "+5 Va". For stabilization of "+100 Va", are used U1, U2, 9, 12 and Ufb1. Converter B works similarly to $\mathrm{A}$. Converter $\mathrm{C}$ produces one output voltage "+ $5 \mathrm{Vd}$ " and one galvanically bound signal PG for telemetry, for authentication of the working capacity.

For the device "DP" in BN are used circuit breakers type BSK5E5-32, for which there are electrical and time parameters for the starting current. They are shown in the Table. 2.

Table 2. Characteristics of the circuit breakers for the BN type BSK5E5-32

\begin{tabular}{|c|c|c|c|c|c|c|c|c|c|}
\hline Io & {$[\mathrm{A}]$} & 1.5 & 2.5 & 4 & 6 & 8 & 10 & 14 & 18 \\
\hline To & {$[\mathrm{s}]$} & 0.05 & 0.15 & 0.20 & 0.30 & 0.40 & 0.60 & 0.80 & 1.00 \\
\hline Iz & {$[\mathrm{A}]$} & 0.5 & 0.7 & $1-1.5$ & 2.5 & $3-3.5$ & 4 & 5 & 7 \\
\hline Tpr & {$[\mathrm{s}]$} & 1 & 2 & 4 & 7 & 10 & 15 & 20 & 30 \\
\hline
\end{tabular}

Time diagram the factory setting for БСК5Э5-32 are indicated on Fig. 8. Maximum values are indicated in orange and purple, and green is the permissible starting current. The following abbreviations are used:

- Io: the maximum value in the plus bus of the onboard network, in excess of which is unconditionally and immediately disconnected power;

- To: the maximum time for completion of transition processes after command switching device.

- Iz: the value of the overload current (for the time interval Tpr), in excess of which turns off the power of the device; 
- $\mathbf{T p r}$ - the time allowed for the occurrence of the overload current of the device after that triggers the switch to the positive bus of the battery.

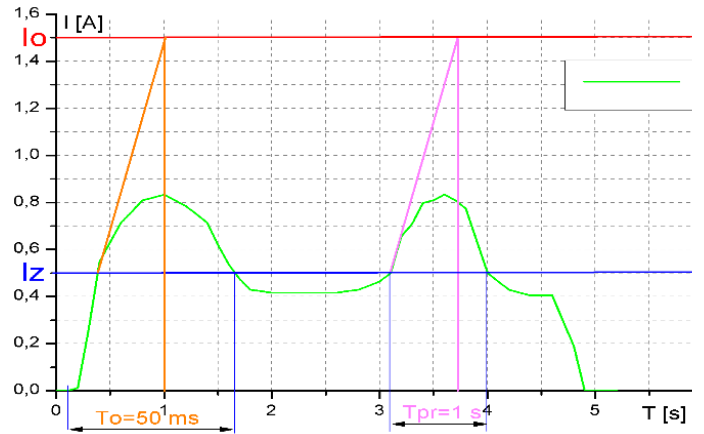

Fig. 8. Time diagram of БСК5Э5-32 from BN of ISS

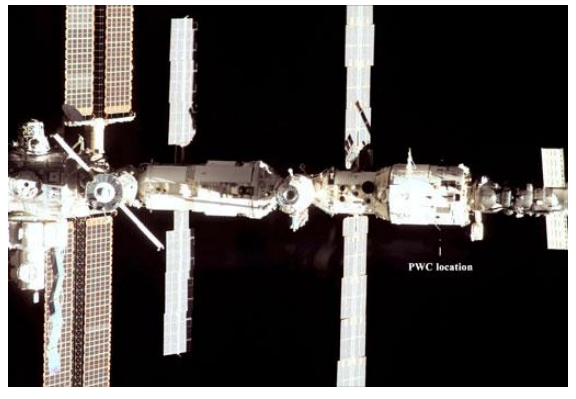

Fig. 9. PWC location of ISS [6].

\section{Results}

The exit of ISS cosmonauts Pavel Vladimirovich Vinogradov and Roman Romanenko in outer space took place for PWC equipment installation on the external surface of the Service Module of Russian Segment of ISS in April 2013; see Fig. 9 [6]. Power consumption of the device DP is not more than $2.2 \mathrm{~W}$. Peak value of inrush current $=0.35 \mathrm{~A}$ for the $\mathrm{BN}$ in the range of 17-36 $\mathrm{V}$ that means that these values apply to the entire range. The time of starting the process $\mathrm{t}_{\text {пуск }}=3-5 \mathrm{mS}$. The value of the tripping current protection is $\mathbf{I z}=0.35$ A. Protection of SPS-DP turns off the DP after time $70 \mathrm{mS}$ [7].

\section{Discussion}

On April 23, 2014 was the first anniversary of functioning of scientific equipment in the frame of space experiment "Obstanovka-1 stage" on board the Russian segment of the ISS [6]. The data from experiments with DP devices allow recording of physical events and monitoring of the parameters of low temperature plasma near to the board of ISS. The DP system provides opportunities for monitoring and processing of the information obtained in the laboratory for the work period (4 years) [1]. 


\section{References}

1. Bachvarov, D., A. Boneva, B. Kirov, Y. Boneva, G. Stanev, and N. Baruh. Primary information pre-processing system for LP, DP devices - project "Obstanovka". In: Proceedings of the International Conference „Big Data, Knowledge and Control Systems Engineering” - BdKCSE'2014, November 5, 2014, Sofia, Bulgaria, pp. 65-74, URL: http://conference.ott-iict.bas.bg/wp-content/uploads/2014/01/ BdKCSE2014_Pre.pdf

2. Klimov, S. I., V. E. Korepanov, Yu. V.Lissakov, O. V. Lapshinova, I. V. Sorokin, S. A. Belyaev, G. A. Stanev, K. Georgieva, B. Kirov, M. P. Gough, H. S. C. K. Alleyne, M. Balikhin, J. Lichtenberger, Cs. Ferencz, L. Bodnar, K. Szego, S. Szalai, J. Juchiewicz, H. Rothkaehl, and K. Stasiewicz, "Obstanovka" experiment onboard International Space Station for space weather research. URL: http://www.rmki.kfki.hu/ szalai/Publications/Klimov-ESTEC-2002Ostanovka.pdf

3. Project OBSTANOVKA 1-st stage. URL: http://www.obstanovka.free.bg.

4. The project "Charge-ISS" is the Study of near-surface processes of polarization of a spacecraft of an extra-large size (of the International space station - ISS), 2006-2010. URL: http://www.ras.ru/presidium/documents/directionsp.aspx?ID= 928925e5-f80e-462f-b441-ee25cf492833\&print=1

5. International Space Station Program. NASA/RSA Joint Specifications/Standards Document for the ISS Russian Segment, SSP 50094, Revision A, NASA, Johnson Space Center Houston, Texas, March 10, 2000. 551 p. URL: http://everyspec.com/NASA/NASA-JSC/NASA-SSP-PUBS/SSP_50094A_29695/

6. Space experiment "OBSTANOVKA 1-st stage" on Russian Segment of ISS http://www.iki.rssi.ru/obstanovka/eng/participants.htm

7. Neychev, S., St. Klimov, A. Anev, N. Baruh, L. Belyakova, A. Belikova, A. Boneva, A. Buzekova, D. Buchvarov, G. Galev, V. Grushin, M. Zaharinova, I. Ivanov, O. Lapshina, R. Nedkov, D. Novikov, V. Myagkih, P. Gramatikov, V. Osipov, G. Stanev, D. Teodosiev, and L. Todorieva, Device for measurement of spacekraft potential of ISS - equipment and first results, In: Proceedings of $9^{\text {th }}$ Scientific Conference with International Participation "SPACE, ECOLOGY, SAFETY" SES 2013, 20-22 November 2013, Sofia, Bulgaria, p. 15-23. http://www.space.bas.bg/BG/magasin/SES/PROCEEDINGS\%20SES\%202013.pdf 


\title{
ВТОРИЧНА ЗАХРАНВАЩА СИСТЕМА ЗА МОНИТОРИ \\ НА КОСМИЧЕСКИ ПОТЕНЦИАЛ ДП-1 И ДП-2, ПРОЕКТ "ОБСТАНОВКА", МЕЖДУНАРОДНА КОСМИЧЕСКА СТАНЦИЯ
}

\author{
П. Граматиков, Р. Недков, Г. Станев
}

\begin{abstract}
Резюме
В статията е представен български прибор, предназначен за изследване на зареждането на Руския сегмент на Международната космическа станция (MКС). Двата еднакви прибора (ДП1 и ДП2) са част от приборите на блоковете на Плазменовълнов комплекс 1 и 2. ДП1 и ДП2 служат и за изследване динамиката на потенциала на МКС в зависимост от: сльнчевата и геомагнитната активност (част от програмата "Космическо време"); дейността на космонавтите по време на работата им на повърхността на станцията; корекциите на орбитата на МКС и скачването и разкачването на космическите кораби с МКС. ДП1 и ДП2 измерват потенциала на корпуса не повече от $3 \mathrm{~m}$ от повърхността на МКС. Пределните диапазони на измерване са: диапазон $\pm 200 \mathrm{~V}$; честотен диапазон от 0 до $500 \mathrm{~Hz}$ и праг на чувствителност на потенциала $3.125 \mathrm{mV}$. Представени са блокови и функционални схеми на прибора ДП и вторичната електрозахранваща система, предназначена за захранването на измервателната сонда, аналоговата и цифровата платки. Представени са три снимки на изработената в България апаратура.
\end{abstract}

